\title{
Energy assessment and optimization of programmed agricultural production using retrospective data
}

\author{
Aleksey Rogachev ${ }^{1,2 *}$, and Elena Melikhova ${ }^{1}$ \\ ${ }^{1}$ Volgograd State Agrarian University, Department of Mathematical Modeling and Informatics, \\ 400075, 26. Universitetsky Ave., Volgograd, Russian Federation \\ ${ }^{2}$ Volgograd State Technical University, Department of Information Systems in Economics, 400131, \\ 28, Lenin Avenue, Volgograd, Russian Federation
}

\begin{abstract}
Theoretical approaches and software implementation of obtaining energy assessment of programmed agricultural production based on the optimization of the parameters of the technologies used are considered. Evaluation of productivity obtained using long-term retrospective data. A linear optimization mathematical model is constructed to justify the parameters of plant growing in a model economy with several fields and crops. Based on the agro-energy assessment of the elements of the technologies used, recommendations are obtained for the optimal distribution of limiting resources according to the specific energy effect criterion, taking into account restrictions on the example of a combination of different irrigation technologies.
\end{abstract}

\section{Introduction}

Energy assessment of the efficiency of technological processes allows to obtain objective estimates of their efficiency by objective criteria, free from temporary market changes in prices, for example, for energy. With regard to agricultural production, in the world practice, the agro-energy indicator characterizing the ratio of the share of energy accumulated in products to the energy spent on its creation is becoming increasingly widespread [1-3]. Energy assessment is used together with traditional methods of assessing the efficiency of agricultural production through cost indicators and labor costs in the framework of food security [4- 6]. This approach is based on the fact that, according to the fundamental law of energy conservation, the totality of resources involved in production is reduced to a single meter - energy, using [7- 9]. At the same time, agricultural production is considered as a complex system, where the input takes into account natural and anthropogenic energy, and the output-the energy accumulated by living organisms, plants, microorganisms in the soil, etc. [1].

In the structure of energy production costs, the main elements are the costs of mineral nutrition, soil cultivation, irrigation water and irrigation, increasing the cost of harvesting. The expediency of introduction and application of the studied technologies from the

\footnotetext{
*Corresponding author: rafr@mail.ru
} 
energy-economic positions is evidenced by their agro-energy efficiency. At the same time, the absolute values of energy intensity of products taking into account the coefficients of energy equivalence show that the increase in energy costs is not always proportional to the effective yield of the economically valuable part of the crop. The yield values were taken by long-term average with possible risks [10], as well as the dynamics of their forecast values [2, 11-13].

Therefore, agro-energy assessment is the most universal method of comparing different technologies, including crop irrigation methods. This approach allows to objectively neutralize the emerging price disparity between the cost of fuel and lubricants and agricultural machinery to the detriment of the final products of agricultural production.

\section{Methods}

When calculating the total energy costs in the study were guided by the methodology of agro-energy assessment of crop production technology [1, 7]. The implementation of the energy approach is considered on the example of a model economy focused on obtaining the planned yield of table beets and potatoes cultivated on irrigation. To determine the optimal values of efficiency indicators of cultivation of agricultural crops on irrigation, it is possible to use production functions, while the productivity of crops, unit costs and efficiency indicators are expressed in energy equivalents. Optimization of parameters of agricultural production in irrigated agriculture can be carried out on the basis of the basic model of agricultural energy effect maximization, the method of construction of which is described, for example, in [1]. The mathematical model of energy optimization should include a target function (TF), in the simplest case linear, as well as a system of resource and technological constraints inherent in the applied technologies. In assessing the productivity of agricultural crops, the construction of trend-seasonal and adaptive models of long-term retrospective data was used [14]. Taking into account the accepted formulation of the optimization problem in the form of a linear programming problem (SLP), a simplex method implemented in various computer programs was used to find a solution. For the computer solution of the formulated problem it is possible to use the add-in "solution Search" of the MS Excel V. 2016 package, providing not only extremum search, but also the automated analysis of stability and reserves of the received solution.

\section{Results}

As a model, a farm was adopted, including $t$ fields with agricultural crops cultivated by various irrigation technologies. The problem of optimizing the parameters of irrigated fields on the example of a model farm, cultivating table beets and potatoes on drip and combined irrigation, can be formulated as follows. According to the initial data to determine the ratio of drip and combined irrigation by the criterion of maximum agricultural efficiency.

Let's denote $X \mathrm{i}$ - the area occupied by the $i$-th culture (ha), and $Y \mathrm{i}$ - the function characterizing the increase in productivity of the $i$-th culture (t/ha) in accordance with the applied technology. The energy equivalent of the yield of the $i$-th crop is denoted by $A$ $(\mathrm{Gcal} / \mathrm{t})$, and the energy equivalent of the supplied irrigation water is denoted by $E$ $\left(\mathrm{Gcal} / 1000 \mathrm{~m}^{3}\right)$.

Taking into account the two irrigation technologies applicable for the model agricultural enterprise on two typical crops, the following mathematical model was constructed, including linear TF and a system of restrictions 


$$
\ni=\sum_{i=1}^{m} X_{i}\left(A_{i} Y_{i}-B N_{i}-C P_{i}-D K_{i}-E M_{I}\right) \rightarrow \max
$$

where Э -agro-energy effect, GJ;

$N, P, K$ - values of introduced nitrogen, phosphorus, potash fertilizers on the $i$-th field, $\mathrm{kg}$ of active substance (d. V.) per 1 ha;

$B=0.0191 ; C=0.0038 ; D=0.0021$ - energy equivalents of the active substance respectively introduced nitrogen, phosphorus and potassium fertilizers, Gcal / kg;

$M \mathrm{i}$ - irrigation norm for $i$-th field, thousand $\mathrm{m}^{3}$.

Resource constraints of the optimization problem are:

$$
\begin{aligned}
& \sum_{i=1}^{m} X_{i} M_{i} \leq W_{\text {орсет }} \\
& \sum_{i=1}^{m} X_{i} N_{i} \leq N_{\text {зап }} \\
& \sum_{i=1}^{m} X_{i} P_{i} \leq P_{\text {зап }} \\
& \sum_{i=1}^{m} X_{i} K_{i} \leq K_{\text {зап }} \\
& \sum_{i=1}^{m} X_{i} \leq S_{C O}
\end{aligned}
$$

where $N_{\text {заn }}, K_{3 a n}, P_{3 a n}$ - stocks of nitrogen, potassium, phosphorus fertilizers, $\mathrm{kg} \mathrm{d}$. V./ra;

$\mathrm{S}_{\mathrm{co}}$ - the area of irrigated crop rotation in the economy, ha.

The condition of nonnegativity of the required variables, due to the use of the simplex method and usually accepted for such a class of problems, has the form

$$
\mathrm{X}_{1, \ldots, \mathrm{X}_{4} \geq 0 .}
$$

To take into account the peculiarities and limitations of the volume of combined irrigation, we will introduce restrictions on the limiting possibilities of MDD, as well as on the required volume of each crop.

$$
\begin{aligned}
& \sum_{i=1}^{m} X_{i} M_{i}^{\text {мд }} \leq W_{\text {ормдд }} \\
& \sum_{i=1}^{m} X_{i} Y_{i} \leq Z
\end{aligned}
$$

where Worset - limited water supply to the farm, thousand $\mathrm{m}^{3}$; $M_{\mathrm{i}}{ }^{\text {mdd }}$ - irrigation norm for MDD of i-th field, thousand $\mathrm{m}^{3}$; $W^{\mathrm{mdd}}$ - limited water supply for MDD, thousand $\mathrm{m}^{3}$;

$\mathrm{Z}$ - the required volume of production of the $i$-th culture.

The initial data for the assessment of energy efficiency on the example of a model economy are presented in table. 1 . 
Table 1. Baseline data for agri-energy efficiency assessment

\begin{tabular}{|c|c|c|c|c|}
\hline Indicator & $\begin{array}{c}\text { Table } \\
\text { beetroot on } \\
\text { drip } \\
\text { irrigation }\end{array}$ & $\begin{array}{c}\text { Table } \\
\text { beetroot on } \\
\text { fine } \\
\text { sprinkling }\end{array}$ & $\begin{array}{c}\text { Potatoes } \\
\text { on drip } \\
\text { irrigation }\end{array}$ & $\begin{array}{c}\text { Potatoes on fine- } \\
\text { dispersed } \\
\text { sprinkling }\end{array}$ \\
\hline $\begin{array}{c}\text { Iculture yield boost function Yi, } \\
\text { t/ga }\end{array}$ & 60 & 65 & 40 & 48 \\
\hline $\begin{array}{c}\text { The energy equivalent of i- } \\
\text { culture Ai, Kcal/t }\end{array}$ & 2,868 & 2,868 & 7,96 & 7,96 \\
\hline $\begin{array}{c}\text { The value of nitrogen fertilizers } \\
\text { in the i-field, Kg of active } \\
\text { substance (kg ac. s.), } N \text { i }\end{array}$ & 120 & 120 & 110 & 110 \\
\hline $\begin{array}{c}\text { The value of the forforfertilizers } \\
\text { introduced on the } i \text {-field, kg ac.s., } \\
P \text { i }\end{array}$ & 80 & 80 & 80 & 80 \\
\hline $\begin{array}{c}\text { The value of potassium fertiliser } \\
\text { input on the } i \text {-field, Kg ac. s., } K \text { i }\end{array}$ & 110 & 110 & 80 & 80 \\
\hline $\begin{array}{c}\text { Irrigation norm for } i \text {-field } \\
M i, 1000 \mathrm{~m}^{3}\end{array}$ & 2,50 & 2,8 & 2,3 & 2,6 \\
\hline
\end{tabular}

Let's make a mathematical model of the problem with numerical parameters according to dependencies (1)-(9).

The target function (TF) and numerical constraints taking into account the data of table. 1 take the form of

$$
\mathrm{L}(\mathrm{X})=165,34 \mathrm{x}_{1}+179,21 \mathrm{x}_{2}+312,23 \mathrm{x}_{3}+375,44 \mathrm{x}_{4} \rightarrow \max ,
$$

a resource constraints and not the negativity of variables

$$
\left\{\begin{array}{c}
120 \mathrm{x}_{1}+120 x_{2}+110 x_{3}+110 x_{4} \leq 8000 \\
80 \mathrm{x}_{1}+80 x_{2}+80 x_{3}+80 x_{4} \leq 5000 \\
110 \mathrm{x}_{1}+110 x_{2}+80 x_{3}+80 x_{4} \leq 6000 \\
0,3 x_{2}+0,3 x_{4} \leq 6 \\
2,5 \mathrm{x}_{1}+2,8 x_{2}+2,3 x_{3}+2,6 x_{4} \leq 150 \\
\mathrm{x}_{1}+x_{2}+x_{3}+x_{4} \leq 50 \\
60 \mathrm{x}_{1}+65 x_{2} \leq 1400
\end{array}\right.
$$

$$
\mathrm{x}_{1} \ldots \mathrm{x}_{4} \geq 0
$$

For the solution of the formulated ZLP including dependences (10) - (12) on numerical data of table.1, used the built-in math package MS Excel v. 2016 add-in "Solution Search".

\section{Discussion}

The solution of the optimization problem by the simplex method using the add-in, these values for drip irrigated plots $\left(\mathrm{x}_{1}=23,3\right.$ hectares; $\left.\mathrm{X}_{3}=6,7 \mathrm{ha}\right)$ and irrigation on the combined ( $x_{2}=0$ ha, $x_{4}=20$ hectares), in which the objective function (10) takes the maximum value $\mathrm{L}(\mathrm{X})=13448.12 \mathrm{Gcal} / \mathrm{ha}$. Published energy calculations of the production of root crops with drip irrigation show that in the structure of total cost of energy most to $70 \%$ of its 
consumption are for working capital (fuel, fertilizer, herbicides, electricity and seeds) [7]. The value of the specific energy intensity of products when using $\mathrm{N}_{140} \mathrm{P}_{120} \mathrm{~K}_{100}$ on these variants was $1.2 \mathrm{GJ} / \mathrm{t}$. on sprinkling irrigation, this figure was $1.3 \ldots 1.5 \mathrm{GJ} / \mathrm{t}$. Energy costs per 1 hectare of sown area increase in accordance with the increase in yield from 26.1...28.1 GJ at the control, to $75.1 \ldots 80.2 \mathrm{GJ}$.

The add-in MS Excel V. 2016 "Solution Search" has an option to build reports on the result and stability of the obtained solution, which allows you to obtain additional information about its features (table. 1,2).

Table 2. Report on optimization results in MS Excel add-in " Solution Search»

\begin{tabular}{|c|c|c|c|}
\hline Variable cells & Name & Initial Value & Final Value \\
\hline$\$ F \$ 2$ & $\begin{array}{l}\text { Estimated value of the objective function } \\
(\max )\end{array}$ & 0,0 & 13438,72633 \\
\hline$\$ B \$ 3$ & $\begin{array}{l}\text { Crop area }(\mathrm{Si}) \text {, hectare (ha) of table beet on } \\
\text { drip irrigation }\end{array}$ & 0,0 & 23,3 \\
\hline$\$ C \$ 3$ & $\begin{array}{l}\text { Crop area }(\mathrm{Si}) \text {, hectare (ha) of table beet in } \\
\text { fine sprinkling }\end{array}$ & 0,0 & 0,0 \\
\hline$\$ D \$ 3$ & $\begin{array}{l}\text { Crop area }(\mathrm{Si}) \text {, hectare (ha) of potato on drip } \\
\text { irrigation }\end{array}$ & 0,0 & 6,7 \\
\hline$\$ E \$ 3$ & $\begin{array}{l}\text { Crop area ( } \mathrm{Si} \text { ), hectare (ha) of potato in fine } \\
\text { sprinkling }\end{array}$ & 0,0 & 20,0 \\
\hline
\end{tabular}

According to the received reports it is visible availability of reserves, resources, values of coefficients of target function and their admissible variations for ensuring stability of the decision that represents available reserves for increase in production (tab. 3).

Table 3. Report on the availability of reserves in the add-in MS Excel " Solution Search»

\begin{tabular}{|c|c|c|c|c|c|}
\hline $\begin{array}{l}\text { Limit } \\
\text { cells }\end{array}$ & Name & Cell Value & Formula & State & Limit \\
\hline$\$ F \$ 11$ & Crop rotation area, hectare & 50 & $\$ \mathrm{~F} \$ 11=\$ \mathrm{G} \$ 11$ & binding & 0 \\
\hline$\$ F \$ 12$ & Minimum beet production, tons & 1400 & $\$ F \$ 12>=\$ G \$ 12$ & binding & 0 \\
\hline$\$ F \$ 6$ & $\begin{array}{l}\text { The value of introduced nitrogen } \\
\text { fertilizers on the i-th field, a } \\
\text { kilogram of active substance, } \mathrm{Ni}\end{array}$ & 5733,34 & $\$ F \$ 6<=\$ G \$ 6$ & $\begin{array}{l}\text { Without } \\
\text { binding }\end{array}$ & 2266,67 \\
\hline$\$ F \$ 7$ & $\begin{array}{l}\text { The value of applied porcelain } \\
\text { fertilizers on the i-th field, kilogram } \\
\text { of active substance, } P i\end{array}$ & 4000 & $\$ F \$ 7<=\$ G \$ 7$ & $\begin{array}{l}\text { Without } \\
\text { binding }\end{array}$ & 1000 \\
\hline$\$ F \$ 8$ & $\begin{array}{l}\text { The value of the applied potash } \\
\text { fertilizer on the i-th field, kilogram } \\
\text { of active substance; } K i\end{array}$ & 4700 & $\$ F \$ 8<=\$ G \$ 8$ & $\begin{array}{l}\text { Without } \\
\text { binding }\end{array}$ & 1300 \\
\hline$\$ F \$ 9$ & $\begin{array}{l}\text { Irrigation rate for fine sprinkling, } \\
M i, 1000 \mathrm{~m}^{3}\end{array}$ & 6 & $\$ F \$ 9<=\$ \mathrm{G} \$ 9$ & binding & 0 \\
\hline$\$ F \$ 10$ & $\begin{array}{l}\text { Irrigation norm } M \text { i for the } i \text {-th field, } \\
M i, 1000 \mathrm{~m}^{3}\end{array}$ & 125,67 & $\$ F \$ 10<=\$ \mathrm{G} \$ 10$ & $\begin{array}{l}\text { Without } \\
\text { binding }\end{array}$ & 24,33 \\
\hline$\$ F \$ 11$ & Crop rotation area, hectare & 50 & $\$ \mathrm{~F} \$ 11=\$ \mathrm{G} \$ 11$ & binding & 0 \\
\hline$\$ F \$ 12$ & Minimum beet production, tons & 1400 & $\$ F \$ 12>=\$ G \$ 12$ & binding & 0 \\
\hline$\$ F \$ 6$ & $\begin{array}{l}\text { The value of introduced nitrogen } \\
\text { fertilizers on the i-th field, a } \\
\text { kilogram of active substance, } \mathrm{Ni}\end{array}$ & 5733,33 & $\$ F \$ 6<=\$ \mathrm{G} \$ 6$ & $\begin{array}{l}\text { Without } \\
\text { binding }\end{array}$ & 2266,67 \\
\hline$\$ F \$ 7$ & $\begin{array}{c}\text { The value of applied porcelain } \\
\text { fertilizers on the i-th field, kilogram } \\
\text { of active substance, } P i\end{array}$ & 4000 & $\$ F \$ 7<=\$ G \$ 7$ & $\begin{array}{l}\text { Without } \\
\text { binding }\end{array}$ & 1000 \\
\hline$\$ F \$ 8$ & $\begin{array}{c}\text { The value of the applied potash } \\
\text { fertilizer on the i-th field, kilogram } \\
\text { of active substance; } K i\end{array}$ & 4700 & $\$ F \$ 8<=\$ \mathrm{G} \$ 8$ & $\begin{array}{l}\text { Without } \\
\text { binding }\end{array}$ & 1300 \\
\hline$\$ F \$ 9$ & $\begin{array}{c}\text { Irrigation rate for fine sprinkling, } \\
\qquad M i, 1000 \mathrm{~m}^{3}\end{array}$ & 6 & $\$ F \$ 9<=\$ G \$ 9$ & binding & 0 \\
\hline$\$ F \$ 10$ & $\begin{array}{l}\text { Irrigation norm Mi for the } \mathrm{i} \text {-th field, } \\
\qquad M i, 1000 \mathrm{~m}^{3}\end{array}$ & 125,67 & $\$ F \$ 10<=\$ G \$ 10$ & $\begin{array}{l}\text { Without } \\
\text { binding }\end{array}$ & 24,33 \\
\hline
\end{tabular}


Table 4. Sustainability Report

\begin{tabular}{|l|l|l|l|l|l|l|}
\hline Variable cells & Name & Value & Cost & Factor & Increase & Reducing \\
\hline \$B \$3 & $\begin{array}{l}\text { Crop area (Si), hectare } \\
\text { (ha) of table beet on } \\
\text { drip irrigation }\end{array}$ & 23,33 & 0 & 165,34 & 146,89 & 34,25 \\
\hline $\begin{array}{l}\text { Crop area (Si), hectare } \\
\text { (ha) of table beet in fine } \\
\text { sprinkling }\end{array}$ & 0 & $-37,10$ & 178,74 & 37,10 & $1 \mathrm{E}+30$ \\
\hline \$D\$3 & $\begin{array}{l}\text { Crop area (Si), hectare } \\
\text { (ha) of potato on drip } \\
\text { irrigation }\end{array}$ & 6,667 & 0 & 312,23 & 34,25 & 146,89 \\
\hline $\begin{array}{l}\text { Crop area (Si), hectare } \\
\text { (ha) of potato in fine } \\
\text { sprinkling }\end{array}$ & 20 & 0 & 374,97 & $1 \mathrm{E}+30$ & 37,10 \\
\hline
\end{tabular}

Table 5. Margin Intervals

\begin{tabular}{|c|c|c|c|c|c|c|}
\hline Variable cells & Name & $\begin{array}{l}\text { Final } \\
\text { Value }\end{array}$ & $\begin{array}{l}\text { Shadow } \\
\text { price, } \\
\text { rub }\end{array}$ & $\begin{array}{l}\text { Limit } \\
\text { Right } \\
\text { side }\end{array}$ & $\begin{array}{l}\text { Valid } \\
\text { Increase }\end{array}$ & $\begin{array}{l}\text { Valid } \\
\text { Reducing }\end{array}$ \\
\hline$\$ F \$ 11$ & $\begin{array}{l}\text { Crop rotation area, } \\
\text { hectare }\end{array}$ & 50 & 312,23 & 50 & 10,58 & 6,67 \\
\hline$\$ F \$ 12$ & $\begin{array}{l}\text { Minimum beet } \\
\text { production, tons }\end{array}$ & 1400 & $-2,45$ & 1400 & 400 & 1400 \\
\hline$\$ F \$ 6$ & $\begin{array}{l}\text { The value of } \\
\text { introduced nitrogen } \\
\text { fertilizers on the } i \text {-th } \\
\text { field, a Kg of active } \\
\text { substance, } N i\end{array}$ & 5733,33 & 0 & 8000 & $1 \mathrm{E}+30$ & 2266,67 \\
\hline$\$ F \$ 7$ & $\begin{array}{l}\text { The value of applied } \\
\text { porcelain fertilizers on } \\
\text { the } i \text {-th field, } \mathrm{Kg} \text { of } \\
\text { active substance, } P i\end{array}$ & 4000 & 0 & 5000 & $1 \mathrm{E}+30$ & 1000 \\
\hline$\$ F \$ 8$ & $\begin{array}{l}\text { The value of the } \\
\text { applied potash } \\
\text { fertilizer on the } i \text {-th } \\
\text { field, Kg of active } \\
\text { substance; } K i\end{array}$ & 4700 & 0 & 6000 & $1 \mathrm{E}+30$ & 1300 \\
\hline$\$ F \$ 9$ & $\begin{array}{l}\text { Irrigation rate for fine } \\
\text { sprinkling, } M i, 1000 \\
\mathrm{~m}^{3}\end{array}$ & 6 & 209,14 & 6 & 2 & 6 \\
\hline$\$ F \$ 10$ & $\begin{array}{l}\text { Irrigation norm for the } \\
i \text {-th field, } M i, 1000 \mathrm{~m}^{3}\end{array}$ & 125,67 & 0 & 150 & $1 \mathrm{E}+30$ & 24,33 \\
\hline
\end{tabular}

It is also interesting to analyze the energy efficiency of production within the specified limits for years of different availability of natural precipitation (Fig. 1). The presented dependences characterize the change in the energy effect of production, which falls with a decrease in precipitation and, accordingly, an increase in the demand for irrigation water. 


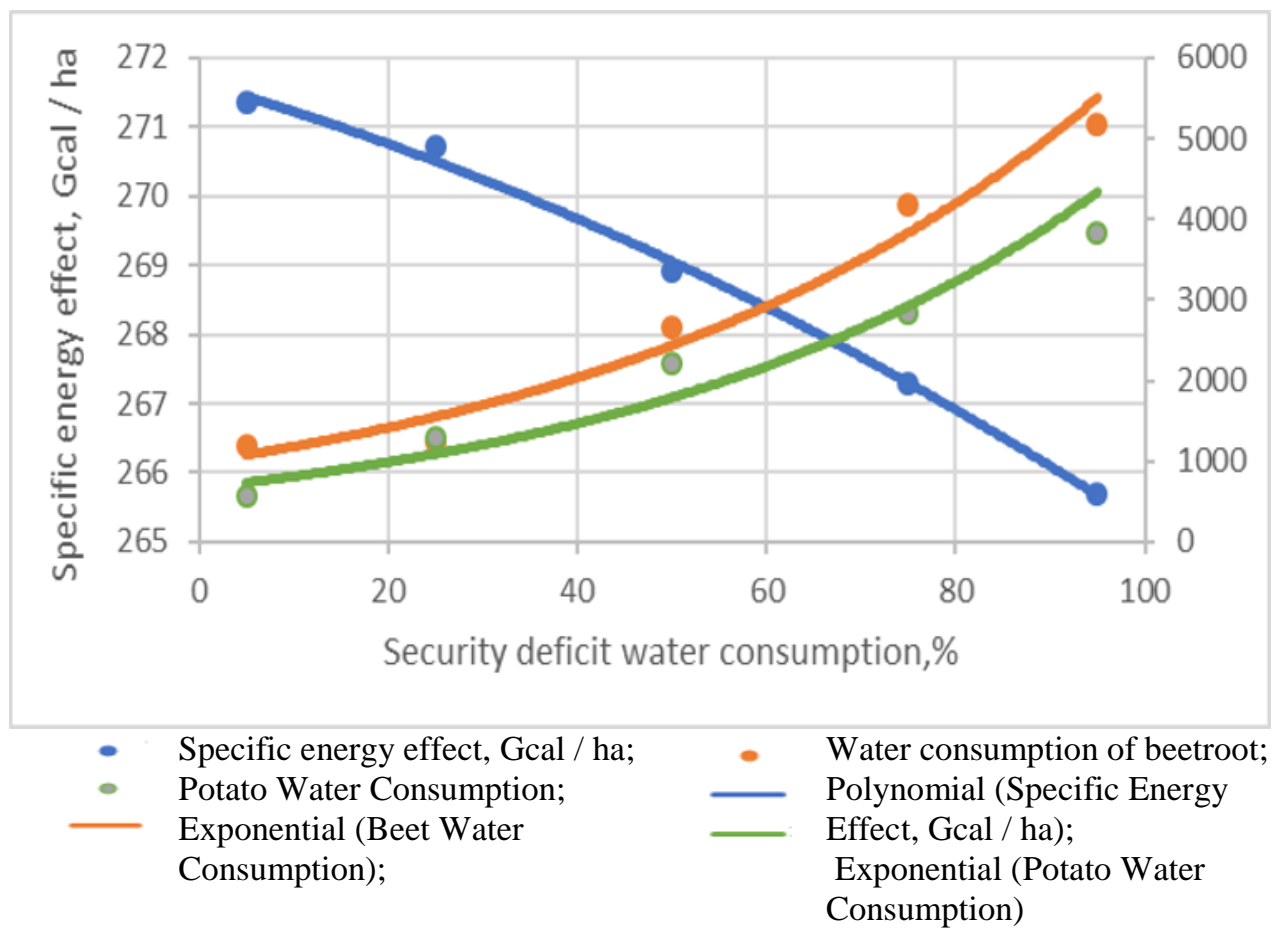

Fig.1. Dependence of a specific energy effect on water supply

The study only partially takes into account the stochastic nature of the simulated phenomena through the inclusion of estimates of long-term productivity indicators in the developed models based on their retrospective data, so the continuation of research is expected to use more complex nonlinear neural network and / or fuzzy cognitive mathematical models $[3,9,11,15]$.

\section{Summary}

1.The constructed optimization model in the form of a linear programming problem (RLP) allows to justify the optimal distribution of limited resources for the simulated fields on irrigated areas of fields with different crops.

2. When solving the optimization problem, it is possible to determine the maximized values of the specific efficiency of agricultural production in energy units per unit area with different combinations of technical and energy coefficients, the volume of resources, the years of moisture supply and other factors.

The work was carried out with the financial support of the RFBR and the administration of the Volgograd region under project No. 19-416-340014 "Creation of a neural network control system for programmable agricultural production using retrospective data and remote sensing results for arid conditions of the Volgograd region".

\section{References}

1. P. Ivanov, Tkachenko I. Economic and mathematical modeling in agriculture: 254 (2013) 
2. A. Rogachev, Mathematical modeling of economic dynamics in agricultural production, $172(2014)$

3. V. Shchedrin, Balakai G. Scientific journal Of the Russian research Institute of reclamation problems, 3 (15), 1-15 (2014)

4. A. Rogachev, T. Mazaeva, E. Egorova, Asian Social Science, 20, 185-192 (2015)

5. A. Rogachev, T. Mazaeva, A. Shokhnekh, Revista Galega de Economia, 2, 87-94 (2016)

6. A. Rogachev, E. Melikhova, A. Shokhnekh, Espacios. 1, 1(2018)

7. E. Melikhova, Modeling and justification of resource-saving parameters of drip irrigation in the cultivation of root crops, 112 (2017)

8. A. Rogachev, Science and higher professional education, 2, 144-151. (2009)

9. I. Yurchenko, A. Nosov, Water economy of Russia: problems, technologies, management, 2, 53-66 (2015)

10. V. Perepelitsa, E. Popova, Mathematical modeling of economic and social risks, $126(2001)$

11. A. Rogachev, M. Subnav, Science and higher professional education,4, 226-231 (2012)

12. A.V. Nikitina, V.M. Kozlov, A.A. Filina, Computational Mathematics and Information Technologies, 1, 35-49 (2019)

13. A. Rogachev, N. Turakova, Kovzalov N. Economic-mathematical modeling grain yield in the Lower Volga region, AIC: Economy, management. 4 56-57 (2008)

14. A. Rogachev, Management of economic systems: electronic scientific journal, 3, 0421100034 (2011)

15. A. Rogachev, E. Melikhova, A. Shokhnekh, Espacios, 27, 4 (2017) 